the field of coffee presents a sheet of white. These flowers are frequented by immense numbers of bees, of two kinds, one about three-quarters of an inch long and black, the other smaller and with white bands round its abdomen. The stigmas now are covered with pollen, and the anthers bursting, and the larger of these bees may be seen buzzing from flower to flower sweeping up the grains of pollen between its front legs, and rolling them into balls. Long before evening all the anthers are exhausted of pollen, and the insects have departed. Besides bees some butterflies visit coffee, such as Hypolimnas bolina, Papilio Polymnestis, and two or three Danaide.

The coffee plant by being proterogynous is intended by Nature to be cross-fertilized, but owing to all the plants in one clearing being usually grown from seed of a single estate, there must be a great deal of interbreeding, more especially as all the coffee of Ceylon and most of South India is supposed to be descended from a single plant introduced into Batavia about two centuries ago. This may have something to do with the manifest deterioration in stamina of the younger coffee.

While on this subject I may mention the curious alteration in the position of the organs of Clerodendron infortunatum when flowering. This plant is proterandrous : at first the style hangs
2.

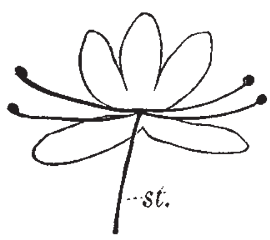

First position.
3.

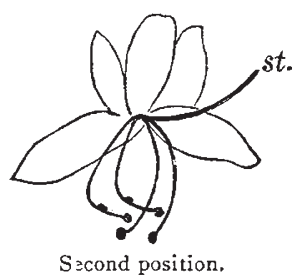

S zcond position. down, while the stamens are erect : as soon as the pollen is shed the stamens drop, while the style rises, and the stigma becomes receptive. The chief carriers of pollen in this plant are smal ants. T. F. BOURDILLON.

Quilon, S. Travancore, India, September 13.

\section{Pearls of Jasininum Sambac.}

Dr. Riedel tells us in NATURE of September 15 (p. 46I), that he possesses in his collection two melati pearls of Jasminum Sambac. I beg to say that, as in the case of tabasheer (see NATURE, vol. xxxvi. p. 30), and in that of cocoa-nut pearls (ibid. p. I58), Rumphius, in the almost inexhaustible treasure of his "Herbarium Amboinense," has already mentioned the pearls found also in the flowers of Jasminum Sambac. $\mathrm{He}$ gives in his fifth volume, in the 3oth table, a good picture of that plant, and says in the description that a "dendrites" found in its flower in 1672 was sent to him two years after. It had the shape of a bud of the same vegtable, and was whitecoloured and hard like silica or alabaster; moreover, it must have been without doubt a carbonate of calcium or some other alkaline earth, for Rumphius remarks that when the pearl was imprudently moistened with citric acid part of it was consumed by the acid. He also tells us that the common name given to all stone-concretions in fruits, wood, and animals by the Malayan people is " mestica," which corresponds well with Dr. Riedel's name of "mustica." ["In Celebe, ac præsertim in Macassara in cunctis, sæpe fructibus dendrites quædam reperiuntur, ubi inter alia in hoc quoque frutice (Jasminum Sambac) talis detecta fuit, quæ loco floris inventa fuit anno 1672 in horto quodam Germani ibi habitantis, quæque mihi biennium post transmissa fuit. Formam habebat capituli, seu instar veri floris Bonga Manoor, nondum aperti, eratque alba et dura instar silicis seu alabastri ; inventa autem fuit in tubo veri floris atque petiolum habebat ex ligno et lapide sensim compositum; quique hanc invenerat, imprudenter in mensa deposuerat, limonum succo commaculata, qui subito eius portionem consumserat."]

Frankfurt a. Oder.

E. HuTh.

\section{Action of River Ice.}

In the year 1854 the Yellow River burst through its left embankment near Kaifung fu, and took a new course to the sea through the province of Shantung, occupying in its lower course the bed of the Tatsing-ho, which it scoured out and widened. Prior to the change the Tatsing-ho had been crossed at Tsiho- hien, about seventeen miles above Tsinan-fu, the provincial capital, by a stone bridge, seven arches of which remained standing in 1868 when Mr. Ney Elias visited the river (see Journal Roy. Geog. Soc. vol. xl. p. 6). Owing to the increased width of the channel, this bridge only reached about threequarters of the distance across the river, and formed a serious impediment to the navigation.

Crossing the river myself at this site in April last, I made inquiries regarding the old bridge, but, as customary in China, could elicit nothing definite; the bridge had gone, and no visible obstruction existed in the channel.

When $I$ arrived in Tientsin in July, the Yellow River was a frequent subject of conversation, and an old friend and wellknown resident, Mr. J. G. Dunn, gave me the following account of a curious phenomenon witnessed by him when crossing the river in January 1883 , on his way overland to Shanghai. The winter was a severe one, and the ice on the Yellow River at this spot was about three feet in thickness. Most of the ordinary traffic of the district was carried across the ice in carts and wheelbarrows; a space was, however, kept open for the ferry, by which usually the entire traffic of the high-road from the capital crosses the river, the ice being broken up every morning so as to leave a clear passage. Mr. Dunn preferred crossing the river by the ferry, as seeming to him more convenient and safer. From the boat he witnessed the extraordinary sight of a stone bridge floating on the upper surface of the ice; the piers had apparently been lifted bodily up, some of the arches were standing, still supported at one end by an abutment, but some had fallen, and were resting as they fell in order on the surface of the ice. The bridge had apparently floated some distance down; Mr. Dunn thought, from the confused answers of the people, a considerable distance, but from a comparison of the site it could scarcely have been more than a hundred yards or so. Strong westerly winds had been blowing for some time, and probably had, combined with other causes, induced a slight rise in the level of the water sufficient to break the connexion of the ice-sheet with the banks; the space kept open for the ferry had enabled it to move downwards by degrees under the influence of wind and current, and as the piers of bridges in China are usually built without cement they offered little obstruction to the movement.

From my own experience of the people in the district I can understand Mr. Dunn's mistake as to the distance the bridge was carried, and there can be no doubt that the bridge seen was the original one described by Mr. Elias.

The fact of a bridge lifted bodily off its piers by the floating power of river ice is probably unique, but in any case is sufficiently interesting to be worthy of record. I may add that the latitude of Tsiho is approximately $36^{\circ} 40^{\prime} \mathrm{N}$., and the width of the river about 2000 feet.

Shanghai, August 26.

\section{Unusual Rainbow.}

A RAINBOW after sunset is probably a somewhat unusual occurrence, but on the evening of September I I I witnessed a very beautiful one from the band-stand in the Alfred Park, which is about the highest ground in Allahabad. Just before sunset the sky was more or less covered with high cirro-stratus, and promised one of the very highly-coloured sunsets common in the rainy season, while at the same time a slight storm, heralded by distant thunder, was coming up from the east. After spending a few minutes in the Public Library near the band-stand, I came out, and found the sun had set behind a bank of what A bercromby calls "rocky cumulus," or some other lumpy form of cloud, and was sending long shafts of alternate light and shadow across the southern half of the sky, while towards the north and overhead the clouds were lighted up with the most gorgeous colours. On turning to the east to see whether the flutings of the cloud-shadows appeared to meet in that quarter, as they usually do, I saw on the approaching shower, which was towards east-south-east, a beautiful double rainbow, both arcs being some $20^{\circ}$ long, but stopping short of the horizon by $1_{2}^{\circ}$ or $2^{\circ}$, to which height the earth-shadow already extended. Both bows seemed to the eye to be somewhat narrower than usual, and between and beyond them the fluted cloud-shadows appeared, by the illusion of perspective, to converge towards the anti-solar point. The bow must therefore have been produced by the light from a portion only of the sun's disk, shining through a hollow on the top of the western bank of cloud, and doubtless 